The University of Maine

\title{
DigitalCommons@UMaine
}

Earth Science Faculty Scholarship

Earth Sciences

3-20-1996

\section{A Century of Accumulation and Temperature Changes in Dronning Maud Land, Antarctica}

Elisabeth Isaksson

Wibjörn Karlén

Niels Gundestrup

Paul Andrew Mayewski

University of Maine, paul.mayewski@maine.edu

Sallie Whitlow

See next page for additional authors

Follow this and additional works at: https://digitalcommons.library.umaine.edu/ers_facpub

Part of the Atmospheric Sciences Commons, Climate Commons, Geochemistry Commons, Glaciology Commons, and the Hydrology Commons

\section{Repository Citation}

Isaksson, Elisabeth; Karlén, Wibjörn; Gundestrup, Niels; Mayewski, Paul Andrew; Whitlow, Sallie; and Twickler, Mark, "A Century of Accumulation and Temperature Changes in Dronning Maud Land, Antarctica" (1996). Earth Science Faculty Scholarship. 242.

https://digitalcommons.library.umaine.edu/ers_facpub/242 
Authors

Elisabeth Isaksson, Wibjörn Karlén, Niels Gundestrup, Paul Andrew Mayewski, Sallie Whitlow, and Mark Twickler 


\title{
A century of accumulation and temperature changes in Dronning Maud Land, Antarctica
}

\author{
Elisabeth Isaksson, ${ }^{1,4}$ Wibjörn Karlén, ${ }^{1}$ Niels Gundestrup, ${ }^{2}$ Paul Mayewski, ${ }^{3}$ \\ Sallie Whitlow, ${ }^{3}$ and Mark Twickler ${ }^{3}$
}

\begin{abstract}
A mass balance program was initiated in the Vestfjella-Heimefrontfjella area of western Dronning Maud Land during the austral summer of 1988-1989. As a part of this program, spatial and temporal variations in snow accumulation and temperature / stable isotopes are measured using shallow firn cores. In this paper we present surface accumulation data and discuss the climatic implications of the stable isotope records from two shallow firn cores. One 30 -m-deep core, obtained about $200 \mathrm{~km}$ from the coast at 700 $\mathrm{m}$ asl $\left(73^{\circ} 36^{\prime} \mathrm{S}, 12^{\circ} 26^{\prime} \mathrm{W}\right)$, covers the period $1932-1991$. The other core was drilled at about $500 \mathrm{~km}$ from the coast at $2900 \mathrm{~m}$ asl $\left(75^{\circ} 00^{\prime} \mathrm{S}, 2^{\circ} 00^{\prime} \mathrm{E}\right)$ and covers the period 1865 1991. The recent accumulation increase that has been reported from several areas of the Antarctic continent is not present in either of these records. Instead, our coastal record suggests a significant decrease in accumulation, with the strongest trend from about 1975. There is a positive trend in the oxygen isotope signal in both cores, which in the coastal core corresponds to a temperature increase of about $1.8^{\circ} \mathrm{C}$ since the early $1930 \mathrm{~s}$, and in the high-altitude core to about $0.8^{\circ} \mathrm{C}$ since 1865 . However, it is likely that part of this increase in $\delta^{18} \mathrm{O}$ is due to a change of moisture source.
\end{abstract}

\section{Introduction}

Lately, Antarctic mass balance has received increased attention because of the ongoing discussion of an enhanced greenhouse effect, where one of the important questions is how a warming would affect the large ice sheets on Earth. However, the response of ice sheet mass balance to climatic changes is slow, and it is therefore difficult to directly connect any changes in the extent and height of the ice sheet to a changing climate on short timescales. Snow accumulation is considered a more sensitive climatic parameter because it is found to be empirically correlated to the air temperature [Robin, 1977; Fortuin and Oerlemans, 1990; Giovinetto et al., 1990]. An example of the importance of accumulation as a sensitive indicator of temperature changes was demonstrated by Alley et al. [1993] who showed that the precipitation over Greenland increased by $100 \%$ in only 3 years during the transition from the last glacial to the Preboreal. More recent increases in accumulation during the last 30-40 years have been reported for coastal Antarctica [Morgan et al., 1991], the interior ice sheet [Petit et al., 1982] as well as from the Antarctic Peninsula [Peel, 1992]. At this point, any wider implications of these changes are difficult to assess, because glaciological data are sparse from large parts of Antarctica.

\footnotetext{
${ }^{1}$ Department of Physical Geography, Stockholm University, Stockholm, Sweden.

2 The Niels Bohr Institute, Department of Geophysics, University of Copenhagen, Denmark.

${ }^{3}$ Glacier Research Group, Institute for the Study of Earth, Oceans and Space, University of New Hampshire, Durham.

${ }^{4}$ Now at Norwegian Polar Institute, Oslo, Norway.

Copyright 1996 by the American Geophysical Union.

Paper number 95JD03232.

0148-0227/96/95JD-03232\$05.00
}

In this paper we present accumulation and stable isotope data from two firn cores from the Vestfjella-Heimefrontfjella area in Dronning Maud Land (Figure 1), one of the relatively unexplored areas of East Antarctica. Detailed descriptions of the climate and morphology of the area are provided by Jonsson [1988; 1992]. During the Swedish Antarctic Research Program (SWEDARP) 1988-1989, a number of $10 \mathrm{~m}$ firn cores were retrieved from the coast and up to $500 \mathrm{~km}$ inland to determine the spatial and temporal patterns of surface accumulation [Isaksson and Karlén, 1994a]. The data reveal a relatively high-accumulation rate and a welldeveloped $\delta^{18} \mathrm{O}$ stratigraphy, suitable for dating, from the coast and up to $300 \mathrm{~km}$ inland [Isaksson and Karlén, 1994b]. Farther inland, where the accumulation is low, other dating methods such as $\beta$ activity, volcanic chronology, and ion stratigraphy must be used. To extend the accumulation and climatic record, 20- to 30-m-deep firn cores were drilled during the 1991-1992 field season in the area called Ritscherflya and on the inland ice plateau, Amundsenisen (Figure 1).

One 30 -m-deep core site $\left(73^{\circ} 36^{\prime} \mathrm{S}, 12^{\circ} 26^{\prime} \mathrm{W}\right)$ is situated about $200 \mathrm{~km}$ from the coast line and $700 \mathrm{~m}$ asl. This core, named $\mathrm{E}$, was dated using a combination of $\delta^{18} \mathrm{O}$ and the direct current electrical conductivity method (ECM). One inland core $\left(75^{\circ} 00^{\prime} \mathrm{S}, 2^{\circ} 00^{\prime} \mathrm{E}, 2900 \mathrm{~m}\right.$ asl) was drilled about $500 \mathrm{~km}$ from the coast in an area which has been identified as a potential deep-drilling site by the European Programme for Ice Coring in Antarctica (EPICA). This 20-m-deep core, named Epica, was dated using a combination of chemical methods. The chemical data from this core is presented in another paper [Isaksson, 1994].

\section{Methods}

\section{Field and Laboratory}

We used a Polar Ice Coring Office (PICO) light weight corer with a 3 inch barrel and an additional tripod for depths 


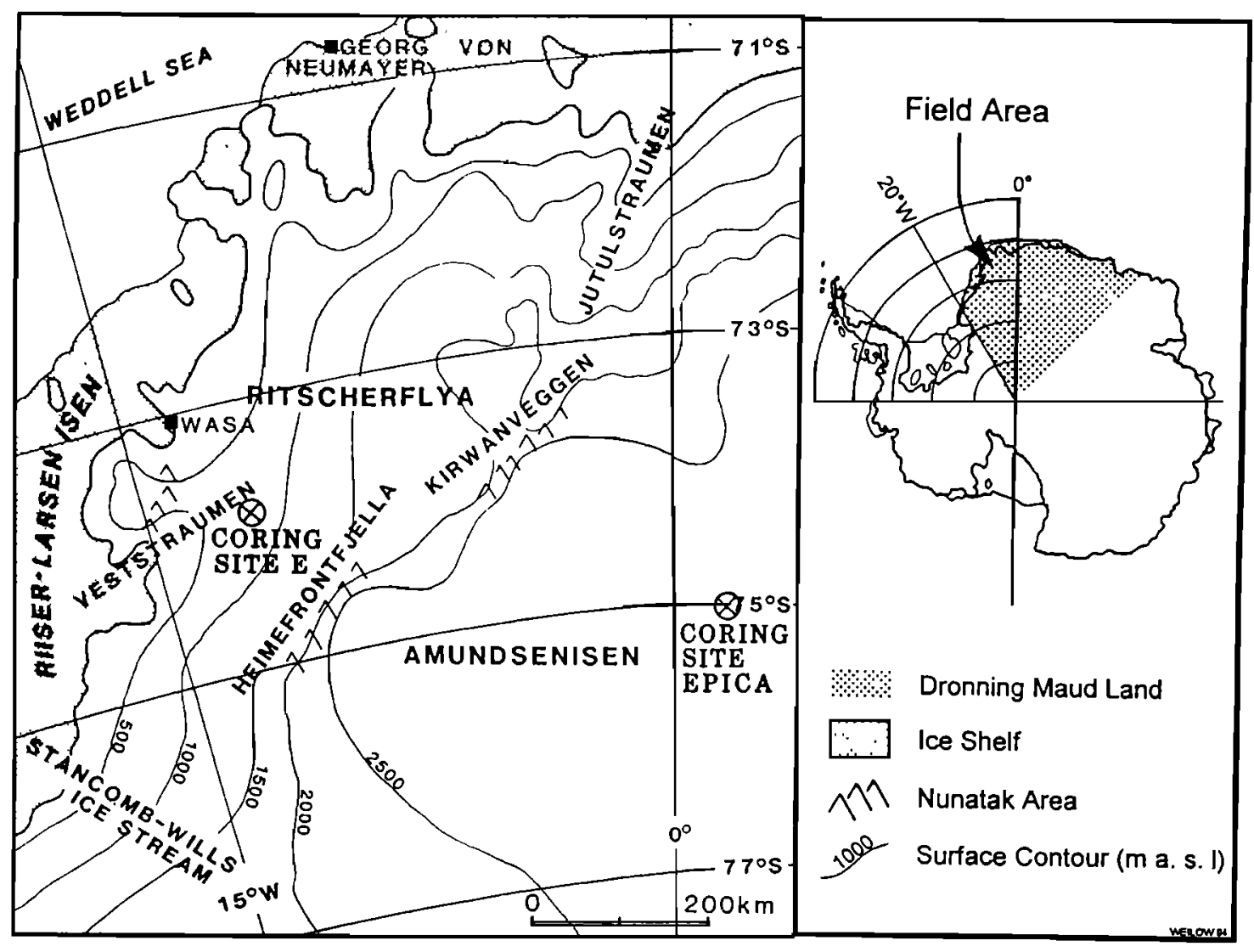

Figure 1. Map of western Dronning Maud Land including the geographical names mentioned in the text and the two coring sites; core E on Ritscherflya and core Epica on Amundsenisen.

below $20 \mathrm{~m}$. The snow/firn density was determined immediately after the retrieval by measuring and weighing each core section on an electronic scale. The snow in the uppermost meter was poorly sintered, and therefore density was measured in a pit where stratigraphic studies and snow sampling were also performed.

The temperature at $10 \mathrm{~m}$ (equivalent to the mean annual temperature) [Loewe, 1970] was measured in the bore hole using a thermo-element calibrated to Celsius with an accuracy of $\pm 0.1^{\circ} \mathrm{C}$. The cable was left in the bore hole for more than 12 hours so that a stable value could be obtained.

The cores were packed in plastic bags and stored in insulated wooden boxes before further transportation to a freezer at the Swedish research station, and later by ship to Sweden. Core $\mathrm{E}$ was subsampled for oxygen isotopic analyses in a cold room $\left(-18^{\circ} \mathrm{C}\right)$. A longitudinal section of each core piece, approximately $2 \mathrm{~cm}$, was removed with a bandsaw and cut into smaller subsamples. The upper $10 \mathrm{~m}$ of the core was cut into $5-\mathrm{cm}$ pieces and the rest of the core into $3-\mathrm{cm}$ pieces, which gave at least 10 samples per accumulation year. The samples were melted in plastic beakers and poured into plastic bottles and refrozen until analyzed with a VG-Fisons Sira Series II mass spectrometer at the Stable Isotope Laboratory at University of Maine.

Core Epica was processed in a cold room $\left(-10^{\circ} \mathrm{C}\right)$ at the University of New Hampshire using special procedures such as particle-free suits, face masks, and tools to minimize contamination [Buck et al., 1992]. About $2 \mathrm{~cm}$ of the outer core section was mechanically cut away to clean the core. The clean sections of the core were put in precleaned (washed with double-deionized water with resistivity $>18 \mathrm{M} \Omega$ ) and dried containers. The $3-\mathrm{cm}$ samples were melted in these containers, aliquots were taken for major ion analysis, methanesulfonic acid (MSA) and oxygen isotopes. The major ions were analyzed within 2 hours of melting, the MSA and $\delta^{18} \mathrm{O}$ samples were refrozen. The cations were analyzed on a CS12 column and the anions on a AS4A-SC, 2-mm column. Both used suppressed chromatography. The analyzing method, including accuracy of the measurements are described by Whitlow et al. [1992]. Oxygen isotopes for this core were analyzed by the stable isotope mass spectrometer at the University of Copenhagen.

The ECM record for both cores was obtained using the standard method for ice developed by Hammer [1980]. Comparison of ECM and ion data from core Epica suggests that the method is applicable on firn as well as ice. These measurements were made during constant temperature conditions at $-18^{\circ} \mathrm{C}$ and with a constant applied voltage of $500 \mathrm{~V}$. A fresh surface was cut in the firn with a microtome knife and the sliding speed was controlled manually. Each core piece was measured several times to ensure the reproducibility of the experiment.

\section{Dating}

The oxygen isotope stratigraphy in core $\mathrm{E}$ shows welldeveloped annual cycles (Figure 2). Annual dating was 


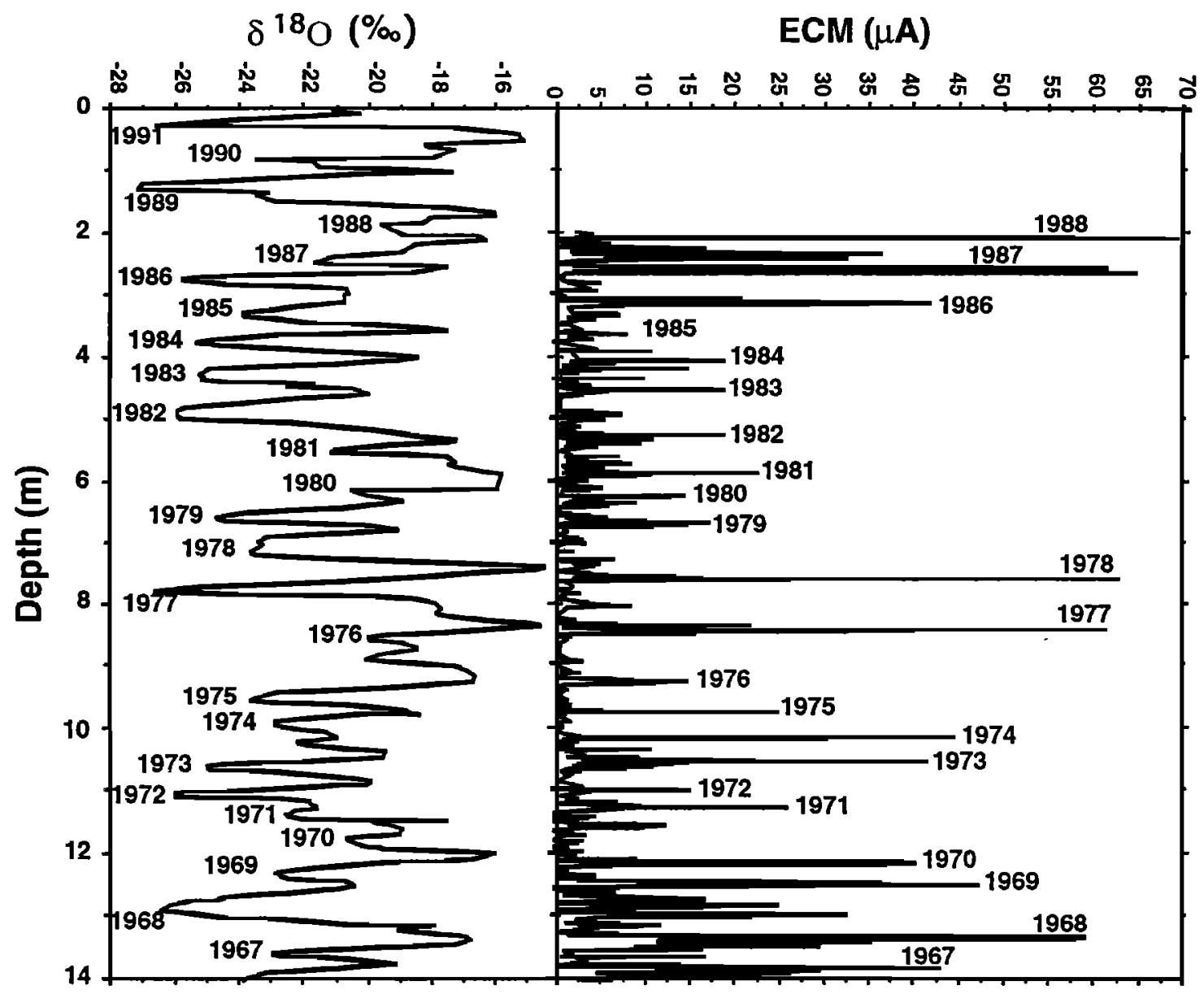

Figure 2. The annual resolution of the uppermost 25 years of the oxygen isotope and ECM records from core $\mathrm{E}$ on Ritscherflya.

obtained by counting the summer peaks, that is the less negative $\delta^{18} \mathrm{O}$ values. The complete stratigraphy, down to $30 \mathrm{~m}$, reveals clear variations in $\delta^{18} \mathrm{O}$, often with an amplitude of $10 \%$. The total range of the $\delta^{18} \mathrm{O}$ values is from $-23.2 \%$ to $-35.9 \%$. The ECM record gave additional control for the dating (Figure 2). Comparing the ECM signal to the seasonal variations in the $\delta^{18} \mathrm{O}$ suggests that the ECM peaks in early autumn. However, this is not definitive because the position of the ECM electrode along the core length was somewhat uncertain.

The $\delta^{18} \mathrm{O}$ stratigraphy in core Epica shows well-developed seasonal variations in the upper $4 \mathrm{~m}$, but below this level the signal amplitude becomes less pronounced and cannot be used for dating. At this depth the density is about $0.42 \mathrm{~g} / \mathrm{cm}^{3}$ and it is likely that the diffusion due to the densification [Johnsen, 1977] in combination with the low annual accumulation and a strong temperature gradient between summer and winter cause this change. Therefore the sodium and the nitrate records, both which show well-developed seasonal variations through the whole record (Figure 3), were used instead. The sulfate record reveals major volcanic eruptions known from other Antarctic ice cores such as Mount Agung and KrakatauTarawera (Figure 3). In addition, some other less well-known eruptions give several more reference horizons. We consider the dating error of core Epica to be of the order of \pm 3 years.
Our previous results suggest that the annual temperature signal from Halley could not be correlated with the annual oxygen isotope record from the Vestfjella-Heimefrontfjella area [Isaksson and Karlén, 1994b]. However, when the signals were smoothed with a filter approximately corresponding to a 5-year running mean filter, they did show better correspondence. A comparison of the Halley annual temperature record and the annual oxygen isotope stratigraphy of core $\mathrm{E}$ do not indicate any major discrepancies back to 1957 (Figure 4). We therefore suggest that the dating error of this core is of the order of \pm 5 years.

The most likely dating error in the cores would be missing annual layers. However, coring site $\mathrm{E}$ is situated along a major stake line between Vestfjella and Heimefrontfjella with stakes placed every $500 \mathrm{~m}$. The accumulation has been measured since 1988 [Holmlund et al., 1989; Näslund et al., 1991; C. Bronge and J. Kuylenstierna, unpublished data, 1993] so the spatial distribution for that time period is well established. Judging from this information, wind erosion has not removed whole annual snow layers in the area around coring site $\mathrm{E}$ since monitoring of the surface accumulation began. However, similar conditions may or may not have occurred before 1988. No stake measurements exists from the area around the Epica coring site. 


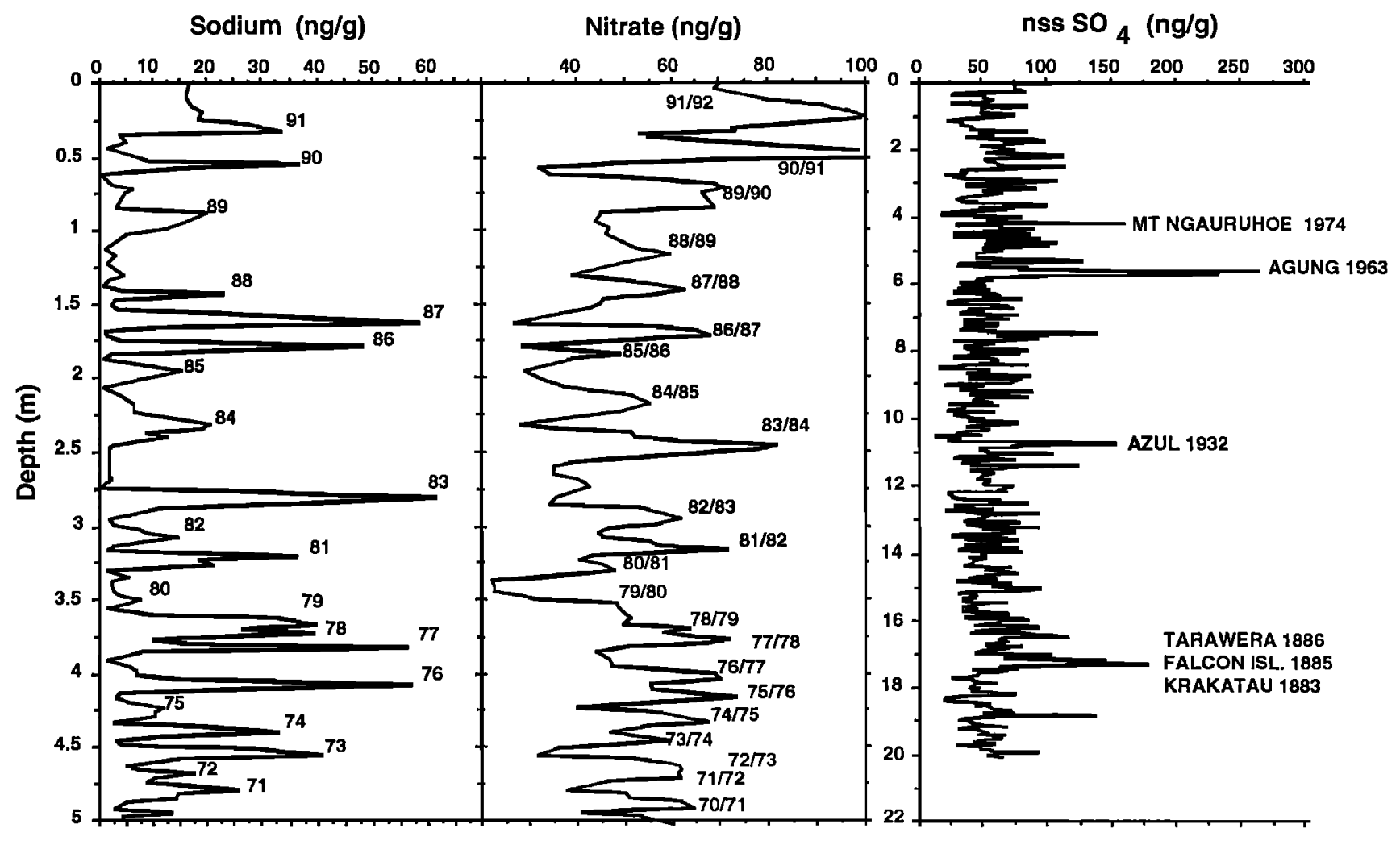

Figure 3. The sodium and nitrate profiles used for dating for the uppermost 21 years and the complete profile of the sulfate record from core Epica on Amundsenisen.

\section{Results and Discussion}

\section{The Accumulation Records}

The core site information and a compilation of the obtained glaciological measurements are presented in Table 1 . The annual accumulation rates were calculated for both cores using the summer peak as the dividing horizon between different years. Both the annual and the smoothed accumulation data are presented in Figure 5. The decadal accumulation rates for both cores and the accumulation between the differ- ent dating horizons in the core Epica are presented in Table 2. The mean annual accumulation for the entire period is 32.4 $\mathrm{cm}$ water equivalents (w. eq.) for site $\mathrm{E}$ and $7.7 \mathrm{~cm} \mathrm{w}$. eq. for core Epica.

The annual accumulation record from core $\mathrm{E}$ shows large interannual variability throughout the whole sequence, which is not uncommon for an accumulation record. Processes such as redistribution by wind tend to be very local, and it is therefore more reliable to look at trends over longer time periods rather than at values from individual years. The accumulation

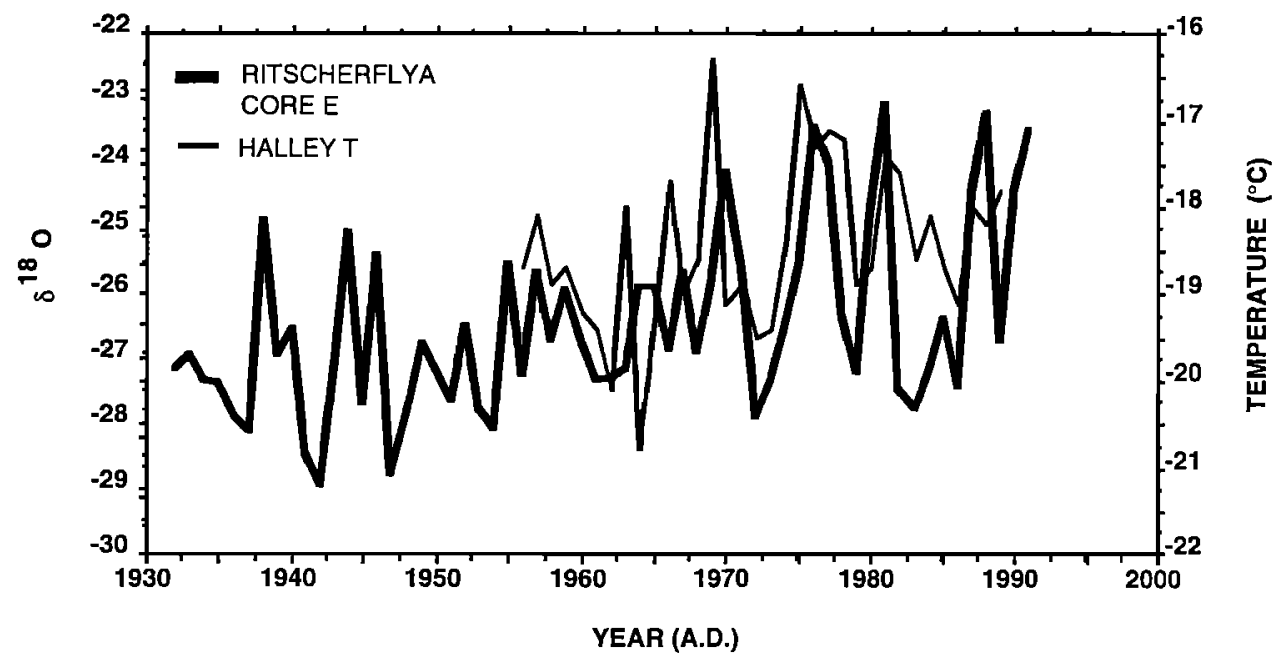

Figure 4. Comparison between the record of annual mean temperature at Halley and the annual mean oxygen isotope record from core $\mathrm{E}$. 
Table 1. Core Site Information

\begin{tabular}{|c|c|c|}
\hline & $\begin{array}{c}\mathrm{E} \\
\text { (Ritscherflya) } \\
\end{array}$ & $\begin{array}{c}\text { EPICA } \\
\text { (Amundsenisen) } \\
\end{array}$ \\
\hline $\begin{array}{l}\text { Position } \\
\text { Latitude } \\
\text { Longitude }\end{array}$ & $\begin{array}{l}73^{\circ} 36^{\prime} \mathrm{S} \\
12^{\circ} 26^{\prime} \mathrm{W}\end{array}$ & $\begin{array}{r}75^{\circ} 00^{\prime} \mathrm{S} \\
2^{\circ} 00^{\prime} \mathrm{E}\end{array}$ \\
\hline Altitude, $\mathrm{m}$ asl & 700 & 2900 \\
\hline Core depth, $m$ & 30.4 & 20.1 \\
\hline $10 \mathrm{~m}$ temperature, ${ }^{\circ} \mathrm{C}$ & -22.0 & -43.8 \\
\hline Time coverage & $1932-1991$ & $1865-1991$ \\
\hline $\begin{array}{l}\text { Mean annual } \\
\text { accumulation, } \\
\text { cm water equivalents }\end{array}$ & 32.4 & 7.7 \\
\hline Mean $\delta^{18} \mathrm{O}$, \%o & -21.5 & -44.8 \\
\hline
\end{tabular}

in this core shows a slightly decreasing trend between 1932 and 1991 (Figure 5a) equivalent to a decrease of about $25 \%$ (significant at the $90 \%$ level). The accumulation decrease is strongest from 1975 to the present. However, it has to be taken into consideration that the filter affects the ends and therefore the trend. A similar decreasing accumulation trend is also evident in the late 1930s and early 1940s and a possible explanation is that the depositional signal is very local and caused by a sastrugi moving across the site. Accumulation time series from a single site, such as in this case, should be viewed cautiously and larger-scale (e.g., regional) interpretations should be avoided without additional supporting evidence. It is, however, interesting to note that accumulation from 1980 to 1989 was found to exhibit a decreasing trend in seven 10-m cores from the Riiser Larsen ice shelf and Ritscherflya [Isaksson and Karlén, 1994a].

In contrast, no clear trend in accumulation is present during the entire period covered by core Epica (1865-1991) (Figure $5 b$ ). While there appears to be a period of low accumulation around 1965 followed by a rapid increase of up to $100 \%$ by 1991 , it is likely that this increase, particularly during the last 3 years, may be an artifact of the sampling since the top of the core was not well preserved. Therefore no definite conclusion for the most recent accumulation rate is possible.

The lack of trend in the low-accumulation area is supported by earlier data from a $10-\mathrm{m}$ core from Amundsenisen $\left(75^{\circ} 05^{\prime} \mathrm{S}, 9^{\circ} 32^{\prime} \mathrm{W}\right)$, about $350 \mathrm{~km}$ west from the core Epica site, obtained 1988-1989. This core was dated using $\beta$ activity horizons, and did not indicate any changes in accumulation between the time periods determined based on these horizons, that is 1955-1965 and 1965-1988 [Isaksson and Karlén, 1994a].

As already mentioned, there have been reports in the literature of accumulation increases from both high- and lowaccumulation areas. Ice core data from the Antarctic Peninsula indicate a major increase in accumulation since 1950 , which coincides with a temperature increase over the same period [Peel, 1992]. Substantial accumulation increases have also been reported from Wilkes Land [Goodwin, 1991;
Morgan et al., 1991]. At Dome C, the increase was estimated to be $30 \%$ from the period $1955-1965$ to the period $1965-$ 1979 [Petit et al., 1982] A similar accumulation increase was also noted at the south pole by Jouzel et al. [1983]. Comparing the data from the high-accumulation sites to our records from coastal Dronning Maud Land, core E indicates a clear difference in trends (Figure 5c), but still we have to be cautious about the effect of local processes.

\section{The Oxygen Isotope Records}

The stable isotope record from core E suggests an increasing trend of $0.036 \% \mathrm{yr}^{-1}$ (significant at the $99 \%$ level) from about 1932 to the present (Figure 6). From our previous work we have determined a gradient of $1.16 \% /{ }^{\circ} \mathrm{C}$ for this area [Isaksson and Karlén, 1994b]. The $\delta^{18} \mathrm{O}$ increase would then translate to a temperature increase of about $1.8^{\circ} \mathrm{C}$ since 1932 , and can be compared to the temperature record from Halley station, the closest meteorological station, which has experienced an increase of $1{ }^{\circ} \mathrm{C}$ since the measurements started in 1957 [Bauer-Hansen, 1992].

The core Epica $\delta^{18} \mathrm{O}$ record also shows an increasing trend, but only $0.006 \% \mathrm{yr}^{-1}, 6$ times less than at the coastal site. The increase in the $\delta^{18} \mathrm{O}$ record is equivalent to a temperature increase of about $0.8^{\circ} \mathrm{C}$ since 1865 (significant at the $99 \%$ level). The warming of the southern hemisphere has been estimated at $0.5^{\circ} \mathrm{C}$ since the end of the last century [Briffa and Jones, 1993], so that the stable isotope record indicated temperature is in the same order of magnitude.

The different magnitude of temperature increase between these two areas could be explained by the fact that highaltitude areas experience a more stable climate than coastal areas, which are affected more by changing sea ice extent and cyclonic activity. The area below $1200 \mathrm{~m}$ asl, the altitude of the Heimefrontfjella mountain range (Figure 1), a likely barrier for cyclones, is probably the most sensitive to such changes in this region. The elevation of the ice surface quickly increases to $>2000 \mathrm{~m}$ asl inland from Heimefrontfjella and to almost $3000 \mathrm{~m}$ asl at the core Epica drilling site. At high elevations, the oxygen isotope record is probably not affected much by variations in moisture source [Bromwich, 
a)

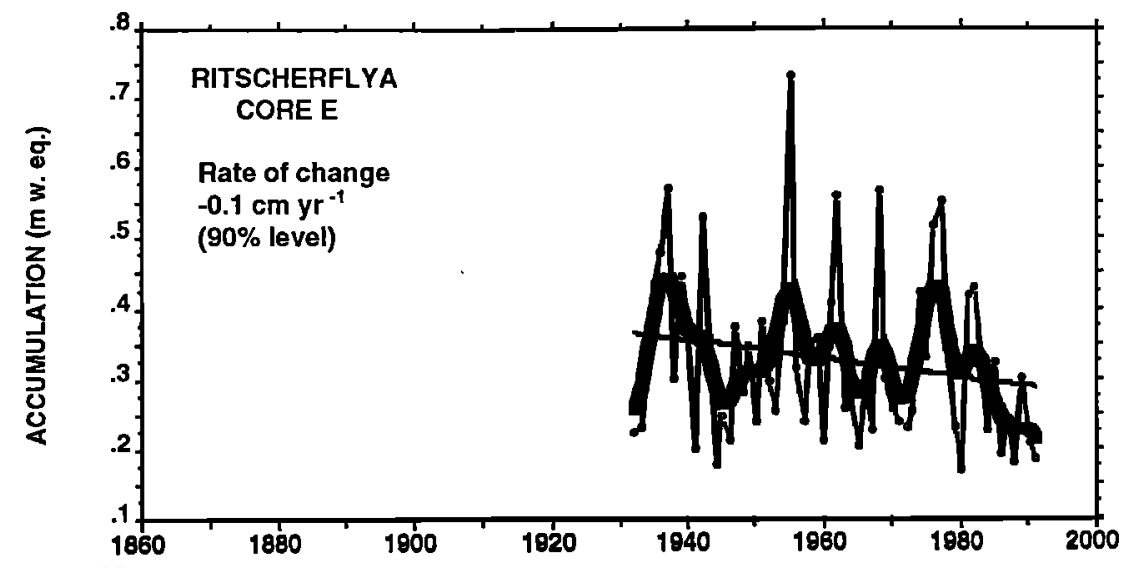

b)

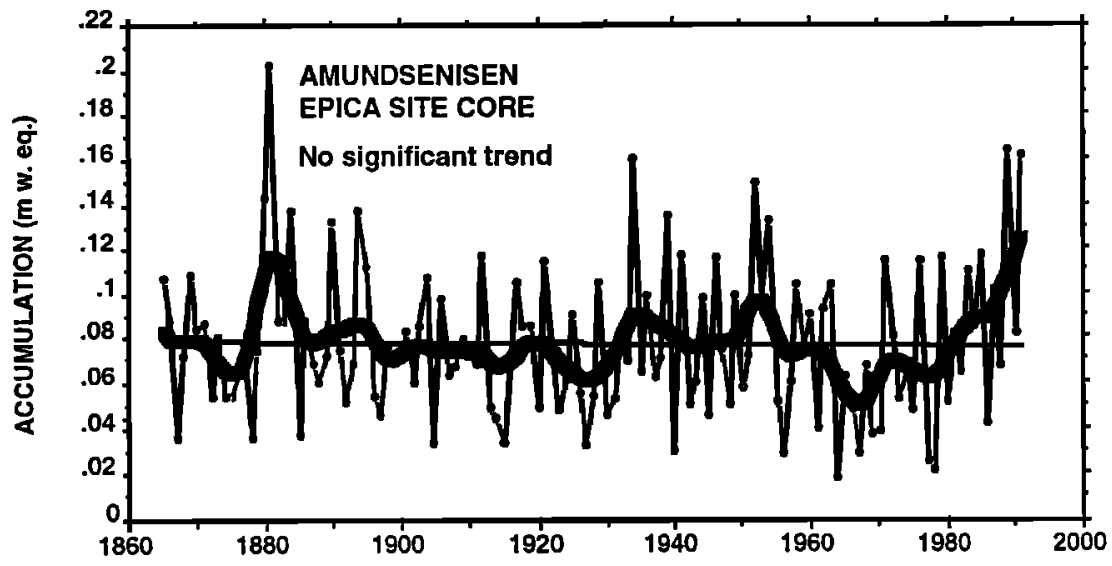

c)

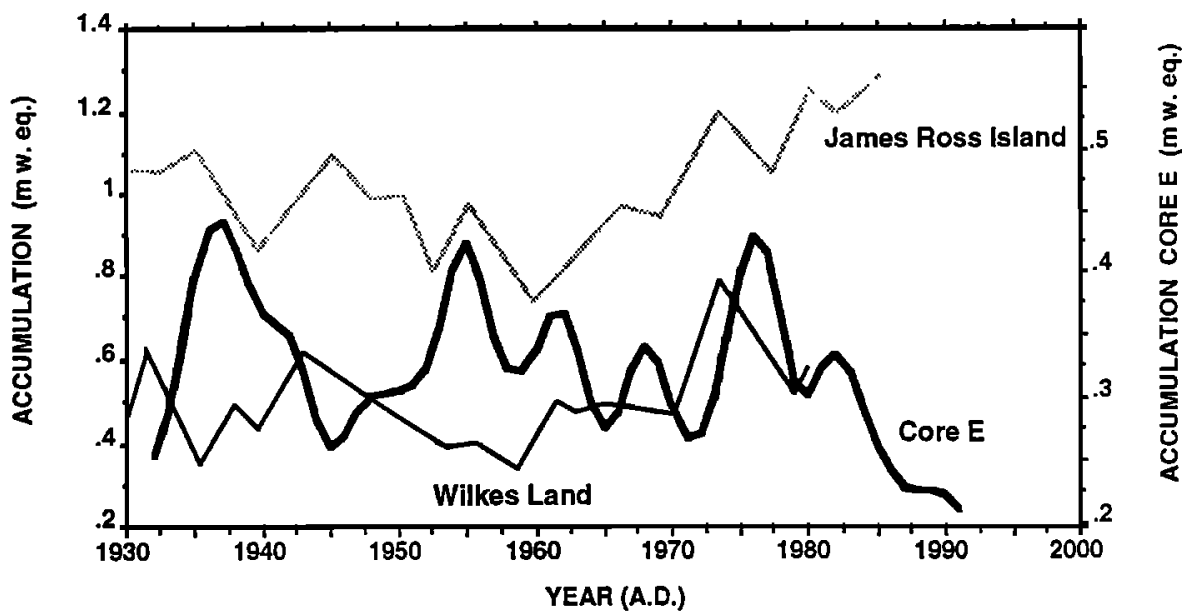

Figure 5. The annual accumulation records from (a) core $E$ on Ritscherflya and (b) core Epica on Amundsenisen. Both records are smoothed using Gaussian weighting coefficients, approximately equal to 7-year moving average. The regression is calculated from the unsmoothed data. (c) Comparison of annual accumulation records from Ritscherflya core $\mathrm{E}$, (thick black line) this work, Wilkes Land (thin black line) [Morgan et al., 1991], James Ross Island (thin grey line) [Peel, 1992]. The accumulation values for core $\mathrm{E}$ are read on the right-hand side of the graph and the value for the two others on the left-hand side.

1988]. A difference between coastal and inland $\delta^{18} \mathrm{O}$ records was indeed suggested by the closer correspondence between the high-altitude oxygen isotope record and the Halley temperature record compared than between Halley and any of the coastal records [Isaksson and Karlén, 1994b].

The source for Antarctic precipitation is presently unknown. On the basis of field observations some authors have suggested the area close to the pack ice edge [Kato, 1978], usually around $55^{\circ} \mathrm{S}$ in the winter, while modeling results suggest a midlatitude, $30^{\circ}-40^{\circ} \mathrm{S}$, source area [Petit et al., 1991]. Because the area of moisture source is not determined, one cannot rule out the importance of the Weddell polynya for this area of Antarctica. The last polynya appeared during the winters of 1974-1977 [Carsey, 1980] and presumably increased moisture content in the air during the winter. However, no changes can be recognized in the firn core records for this time period. By investigating the deuterium excess, which is directly affected by kinetic changes, one may obtain 
Table 2. Comparisons of Annual Accumulation Values From Core $\mathrm{E}$ and Core Epica

\begin{tabular}{|c|c|c|}
\hline Time Period & $\begin{array}{l}\text { Accumulation, } \\
\text { cm water } \\
\text { equivalents }\end{array}$ & $\begin{array}{c}\text { Deviation } \\
\text { from Average, } \\
\%\end{array}$ \\
\hline \multicolumn{3}{|c|}{ Core $E$} \\
\hline $\begin{array}{l}1980-1989 \\
1970-1979 \\
1960-1969 \\
1950-1959 \\
1940-1949\end{array}$ & \begin{tabular}{l|l|}
27.7 \\
33.6 \\
33.0 \\
35.3 \\
30.9
\end{tabular} & $\begin{array}{r}-14.4 \\
3.7 \\
1.9 \\
8.9 \\
-4.5\end{array}$ \\
\hline $1932-1991^{\mathrm{a}}$ & 32.4 & \\
\hline $1973-1988^{b}$ & 32.2 & \\
\hline \multicolumn{3}{|c|}{ Epica Site Core } \\
\hline $\begin{array}{l}1980-1989 \\
1970-1979 \\
1960-1969 \\
1950-1959 \\
1940-1949 \\
1930-1939 \\
1920-1929 \\
1910-1919 \\
1900-1909 \\
1890-1899 \\
1880-1889 \\
1870-1879\end{array}$ & $\begin{array}{l}8.9 \\
6.8 \\
5.9 \\
8.3 \\
7.4 \\
8.4 \\
6.8 \\
7.3 \\
7.5 \\
8.2 \\
9.8 \\
6.7\end{array}$ & $\begin{array}{r}-15.1 \\
12.2 \\
-23.7 \\
7.2 \\
-3.8 \\
9.2 \\
-11.9 \\
-4.9 \\
-2.9 \\
6.5 \\
27.8 \\
-13.5\end{array}$ \\
\hline $\begin{array}{l}1865-1991 \mathrm{c} \\
1964-1991 \mathrm{~d} \\
1884-1991\end{array}$ & $\begin{array}{l}7.7 \\
7.7 \\
7.7\end{array}$ & \\
\hline
\end{tabular}

information about the stability of the moisture source [Johnsen et al., 1989; Peel, 1992]. Unfortunately, we did not have the opportunity to make deuterium analyses on these cores.

Despite the complex relationship between $\delta^{18} \mathrm{O}$ and temperature, the temperature estimates from this investigation appear reasonable. Because the temperature record inferred from the oxygen isotope data is supported by the Halley temperature record (Figure 4) major changes visible in the firn core records most probably reflect regional changes in temperature and precipitation, rather than overall changes in moisture sources.

\section{Implications of Recent Changes in Stable Isotopes Temperatures}

Stable isotope records used as temperature records have improved the geographical distribution of instrumental temperature records from the Antarctic continent, which are few and unevenly spaced. Using oxygen isotope records as climatic indicators requires specific knowledge of the spatial and temporal distribution of oxygen isotopes for the area of interest.
The most commonly used $\delta^{18} \mathrm{O} / \mathrm{T}$ gradient for East Antarctica is $0.75 \% /{ }^{\circ} \mathrm{C}$ [Lorius and Merlivat, 1977]. Our previous studies in the Vestfjella-Heimefrontfjella area, indicate a strong spatial relationship from sea level and up to about $3000 \mathrm{~m}$ asl between the temperature, as interpreted from the $10-\mathrm{m}$ bore hole temperature and the mean $\delta^{18} \mathrm{O}$ in firn cores [Isaksson and Karlén, 1994b]. As already mentioned, the $\delta^{18} \mathrm{O} / \mathrm{T}$ gradient is $1.16 \% /{ }^{\circ} \mathrm{C}$, which is the same order of magnitude as that obtained by Orheim et al. [1986] from this area and by Hermichen et al. [1990] from eastern Dronning Maud Land.

The most thorough statistical analyses on instrumental temperature data from Antarctica was performed by Raper et al. [1984] who noted a discernible increase in temperature from 1960 to the mid 1970s. 1960 seems to have been the coldest year for the period investigated. The pronounced temperature increase after 1980 recorded on the Antarctic Peninsula [Morrison, 1990] cannot be found in the temperature records from the interior of the Antarctic continent. Overall, Raper et al. [1984] found weak correlations between different Antarctic temperature records. On the basis of a study of historical records from early expeditions to Antarctica, Jones 

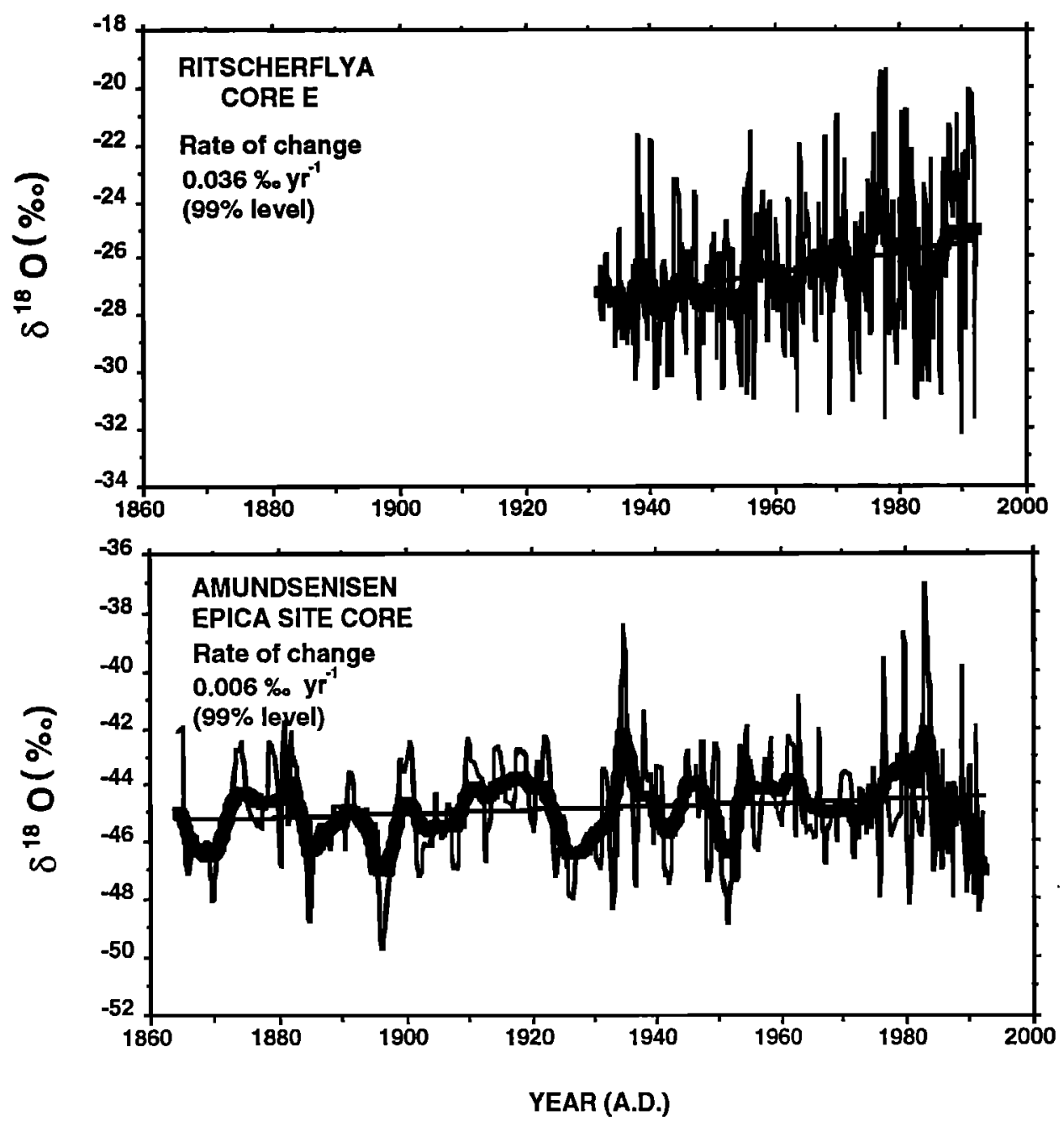

Figure 6. Oxygen isotope records from the two coring locations in Dronning Maud Land; core E at Ritscherflya and core Epica site on Amundsenisen. The records are smoothed using Gaussian weighting coefficients, approximately equal to 20 (Amundsenisen) respectively 60 (Ritscherflya) points moving average.

[1990] estimated that Antarctic air temperatures have increased by at least $1^{\circ} \mathrm{C}$ since the beginning of this century. This should be compared to the estimated warming of $0.5^{\circ} \mathrm{C}$ for the entire southern hemisphere since the end of the last century [Briffa and Jones, 1993]. However, for the last 35 years no correlation was found between the mean annual temperatures for the Antarctic continent and the rest of the southern hemisphere [Jones et al., 1986]. The greatest warming in Antarctica seems to occur on the Antarctic Peninsula and in the Australian sector.

Large interannual temperature variability is well known to complicate direct comparisons between ice core records [Morgan, 1985; Mosley-Thompson et al., 1990]. After investigating several ice core records from Antarctica, Mosley-Thompson [1992] found that the climatic variations between different areas are large and do not necessarily show the same trend. For instance, ice cores records from Mizuho and Law Dome indicate a warming trend after 1850 , while cores from Siple and Filchner-Ronne Ice Shelf show a cooling. Judging from the stable isotope records presented here, the western Dronning Maud Land area also has experienced warming since the mid $1800 \mathrm{~s}$. The results on large variations are not surprising considering that Antarctica, despite its relative homogeneity, is a continent with all the resultant complexities. The importance of an improved spatial distribution of high-resolution paleoclimatic records covering the last centuries cannot be emphasized enough for better understanding climatic variation.

\section{Accumulation Changes as a Climatic Indicator}

The positive empirical relationship between temperature and snow accumulation is widely used in discussions of greenhouse warming and sea level changes [e.g., Oerlemans, 1982; Oerlemans and van der Veen, 1984; Robin, 1988; Zwally, 1989]. However, the oxygen isotope record in core E suggests contemporaneous temperature increase and accumulation decrease. A similar contradictory relationship between temperature and accumulation from the Antarctic Peninsula was discussed by Jones et al. [1993]. They attributed this to either layer thinning at depth due to ice movement, or to changing moisture sources recorded in the oxygen isotope record. Neither of these explanations seem to apply to our field area; because our cores are less than $5 \%$ of the total ice 
depth, it is unlikely that layer-thinning due to ice flow would be a problem. As stated, the correlation between our temperature record and the Halley record suggests that changes in moisture source is minimal.

What could have caused the accumulation decrease in core E drilled in the coastal area? First, there is a possibility that density calculations underestimate the upper part of the core due to the poorly consolidated snow. The density measurements performed in a pit do only cover the last 2 years. However, the stake measurements that have been performed in the coastal areas since 1988 indicate that the accumulation rates estimated from stakes do not differ from the core values for this time period.

Another explanation could be that since precipitation in Antarctica is not evenly distributed over the seasons, temperature changes during part of the year might be sufficient to cause changes in the precipitation pattern. Judging from the Halley record, most precipitation events in the Vestfjella area probably occur during the fall, peaking in March [BauerHansen, 1992]. Bauer-Hansen found that an increase in winter temperatures (June-August) caused the positive trend in the annual record. Both the fall (March-May) and spring (September-November) temperatures decreased, while the summer temperatures (December-February) have increased slightly. However, a change in precipitation season would also affect the oxygen isotopic content of the snow.

Yet another possible explanation might be changing trajectories of the cyclones along the coast. If the cyclones do not penetrate as far inland, then the net accumulation could decrease, even if the temperature did not. This argument was used to explain the recent changes in accumulation along the coast of Wilkes Land [Morgan et al., 1991]. Furthermore, it is important to remember that snow accumulation is largely affected by local processes such as erosion and redistribution by wind. In contrast, the oxygen isotopic content should be a more regional climate indicator and therefore this localregional difference could be enough to explain why the trends in accumulation and temperature are different.

\section{Conclusions}

The stable isotope records from both the coastal firm core and the high-altitude core suggest positive temperature trends. In the coastal core the trend corresponds to about $1.8^{\circ} \mathrm{C}$ since the early $1930 \mathrm{~s}$, and in the high-altitude core to about $0.8^{\circ} \mathrm{C}$ since 1865 . These temperature estimates do not include any changes in moisture source. However, the magnitude of the temperature changes are in agreement with the $1{ }^{\circ} \mathrm{C}$ increase recorded at Halley since 1957 and the southern hemisphere warming of $0.5^{\circ} \mathrm{C}$ since the end of the $1800 \mathrm{~s}$, respectively.

The increase in accumulation since 1960 reported in several areas of the Antarctic continent is not evident in any of our records. No trend in accumulation is visible in the high-altitude record, while a decrease of about $25 \%$ in accumulation since 1932 is suggested from the coastal core. The last decade, 1980-1989, experienced the lowest accumulation in the whole record. The accumulation values for the last 5 years are confirmed by stake measurements which suggest that underestimation of the snow density in the cores is not alone responsible for the recent low accumulation. We suggest that the decrease in accumulation is related to either the decrease in fall temperatures as shown in the Halley record, which could affect precipitation negatively, or a change in the cyclonic trajectories. Further work involving satellite images from in this area might provide more clues to help resolving this problem, and more cores from the area and nearby areas would indicate whether this accumulation trend is local or regional.

Acknowledgments. The glaciology project was financed by NFR grant 8058524-3 to Wibjörn Karlén. Economical help with the oxygen isotope analysis came from Hierta-Retzius Foundation, Ymer-80, Andrée Foundation, Mannerfelt Foundation and the Liljevalchs Foundation. Field support came from SWEDARP and Axel Bodin helped with the drilling. The Stable Isotope Laboratory at University of Maine provided the oxygen isotope analyses of the coastal core and University of Copenhagen the inland core. Anders Moberg patiently guided the filtering of the data and gave comments on the manuscript together with Jack Kohler, Gunhild Rosqvist and Karin Holmgren. Critical and constructive reviews that considerably improved the content of this paper were performed by Ellen MosleyThompson and Stefan Hastenrath.

\section{References}

Alley, R.B., et al., Abrupt increase in Greenland snow accumulation at the end of the Younger Dryas event, Nature, 362, 527-529, 1993.

Bauer-Hansen, I., The climate of Halley, The Aurora Prog. Rap. 3, Det Norske Meteorologiske Institutt, Oslo, 1992.

Briffa, K.R., and P.D. Jones, Global surface air temperature variations during the twentieth century, 2, Implications for large-scale high-frequency palaeoclimatic studies, Holocene, 3 (1), 77-88, 1993.

Bromwich, D.H., Snowfall in high southern latitudes, Rev. Geophys., 26 (1), 149-168, 1988.

Buck, C.F., P.A. Mayewski, M.J. Spencer, S. Whitlow, M.S. Twickler, and D. Barrett, Determination of major ions in snow and ice cores by ion chromatography, $J$. Chromatogr. 594, 225-228, 1992.

Carsey, F.D., Microwave observation of the Weddell Polynya, Mon. Weather Rev., 108, 2032-2044, 1980.

Fortuin, J.P.F., and J. Oerlemans, Parameterization of the annual surface temperature and mass balance of Antarctica, Ann. Glaciol., 14, 78-84, 1990.

Giovinetto, M.B., N.M. Waters, and C.R. Bentley, Dependence of Antarctic surface mass balance on temperature, elevation, and distance to open water, $J$. Geophys. Res., 95(D4), 3517-3531, 1990.

Goodwin, I.D., Snow-accumulation variability from seasonal surface observations and firn-core stratigraphy, eastern Wilkes Land, Antarctica, J. Glaciol., 37(127), 383-387, 1991.

Hammer, C.U., Acidity of polar ice cores in relation to absolute dating, past volcanism, and radioechoes, $J$. Glaciol., 25(93), 359-372, 1980.

Hermichen, W.D., P. Kowski, and R. Vaikmäe, An oxygen18 thermometer from snow of northern Queen Mlaud Land/Antarctica, Geodätische und Geophys. Veröffentlichungen, 307-311, Berlin, 1990.

Holmlund, P., E. Isaksson, and W. Karlén, Massbalans, isrörelse och isdynamik, Dep. of Phys. Geogr., Stockholm Univ, Rep. STOUG-NG 73, 66 pp, Stockholm, Sweden, 1989 .

Isaksson, E., Climate records from shallow firn cores, Dronning Maud Land, Antarctica, Ph. D. dissertation, Dep. of Phys. Geogr., Stockholm Univ., Stockholm, Sweden 1994.

Isaksson, E., and W. Karlén, Spatial and temporal patterns in snow accumulation and oxygen isotopes, Western Dronning Maud Land, Antarctica, J. Glaciol., 40 (135), 399-409, 1994a.

Isaksson, E., and W. Karlén, High resolution climatic information obtained from short firn cores, Western Dronning Maud Land, Antarctica, Clim. Change, 26, 421$434,1994 \mathrm{~b}$. 
Johnsen, S.J., Stable isotope homogenization of polar firn and ice, IAHS AISH Publ., II8, 388-392, 1977.

Johnsen, S.J., W. Dansgaard, and J.W.C. White, The origin of Arctic precipitation under present and glacial conditions, Tellus, 4IB, 452-468, 1989.

Jones, P.D., Antarctic temperatures over the present ceniury A study of the early expedition record, J. Clim., 3, 1193$1203,1990$.

Jones, P.D., R. Marsh, T.M.L. Wigley, and D.A. Peel, Decadal timescale links between Antarctic Peninsula icecore oxygen-18, deuterium and temperature, Holocene, 3 (1), 14-26, 1993.

Jones, P.D., S.C.B, Raper, and T.M.L. Wigley, Southern hemisphere surface air temperature variations: 1851-1984, J. Clim. Appl. Meteorol., 25, 1213-1230, 1986.

Jonsson, S., Observations on physical geography and glacial history of the Vestfjella nunataks in western Dronning Maud Land, Antarctica, Rep. STOUG-NG 68, 57 pp., Dep. of Phys. Geogr., Stockholm Univ., Stockholm, Sweden, 1988.

Jonsson, S., Local climate and mass balance of a blue-ice area in western Dronning Maud Land, Antarctica, $Z$. Gletscherk. Glazialgeol., 26 (1), 11-29, 1992.

Jouzel, J., L. Merlivat, J.R. Petit, and C. Lorius, Climatic information over the last century deduced from a detailed isotopic record in the South Pole snow, J. Geophys. Res., 88 (C4), 2693-2703, 1983.

Kato, K., Factors controlling oxygen isotopic composition of fallen snow in Antarctica, Nature, 272, 46-48, 1978.

Loewe, F., Screen temperatures and $10 \mathrm{~m}$ snow temperatures, .J. Glaciol., 9(56), 263-268, 1970.

Lorius, C., and L. Merlivat, Distribution of mean surface stable isotope values in East Antarctica, Isotopes and Impurities, IAHS AISH Publ., 118, 127-137, 1977.

Morgan, V.I., An oxygen isotope - climate record from the Law Dome, Antarctica, Clim. Change, 7, 415-426, 1985.

Morgan, V.I., I.D. Goodwin, D.M. Etheridge, and C.W. Wookey, Evidence from Antarctic ice cores for recent increases in snow accumulation, Nature, 354, 58-60, 1991.

Morrison, S.J., Warmest year on record on the Antarctic Peninsula?, Weather, 45, 231-232, 1990.

Mosley-Thompson, E., Paleoenvironmental conditions in Antarctica since A.D. 1500: ice core evidence, in Climate since A.D. 1500 , edited by R.S. Bradley, and P.D. Jones, Routledge, New York, 1992.

Mosley-Thompson, E., L.G. Thompson, P.M. Grootes, and N. Gundestrup, Little Ice Age (Neoglacial) paleoenvironmental conditions at Siple Station, Antarctica, Ann. Glaciol., 14, 199-204, 1990.

Näslund, J-O., V. Pojhola, and A. Stroeven, Glaciological surveys in Vestfjella and Heimefrontfjella, Dronning Maud Land, Antarctica, 1989/1990, Rep. STOUG-NG 83, 71 pp.,
Dep. of Phys. Geogr., Stockholm Univ., Stockholm, Sweden, 1991.

Oerlemans, J., Response of the Antarctic Ice Sheet to a climatic warming: a model study. J. Clim., 2, 1-11, 1982.

Oerlemans, J., and C.J. van der Veen, Ice Sheet and Climate, D. Reidel, Norwell, Mass., 1984.

Orheim, O., Y. Gjessing, T. Lunde, K. Repp, B. Wold, H. Clausen, and $O$. Liestøl, Oxygen isotopes and accumulation rates at Riiser-Larsenisen, Antarctica, Nor. Polarinst. Skr., 187, 33-47, 1986.

Peel, D., Ice core evidence from the Antarctic Peninsula, in Climate since A.D. 1500, edited by R.S. Bradley, and P.D. Jones, Routledge, New York, 1992.

Petit, J.R., J. Jouzel, M. Pourchet, and L. Merlivat, A detailed study of snow accumulation and stable isotope content in Dome C (Antarctica), J. Geophy. Res, 87 (C6), 4301-4308, 1982.

Petit, J.R., J.W.C. White, N.W. Young, J. Jouzel, and Y.S. Korotkevich, Deuterium excess in recent Antarctic snow, J. Geophy. Res., 96 (D3), 5113-5122, 1991.

Raper, S.C.B., P.R. Mayes, P.D. Jones, and M.J. Salinger, Variations in the surface air temperatures, 3, The Antarctic, 1957-82, Mon. Weather Rev., I08, 1362-1369, 1984.

Robin, G., de Q., The Antarctic Ice Sheet, its history and response to sea level and climatic changes over the past 100 million years, Palaeogeogr., Palaeoclimatol., Palaeoecol., 67, 31-50, 1988.

Robin, G., de Q., Ice cores and climatic change, Phil. Trans. R. Soc. London. B., 280, 143-168, 1977.

Whitlow, S., P.A. Mayewski, and J.E. Dibb, A comparison of major chemical species seasonal concentrations and accumulation at the South Pole and Summit, Greenland, Atmos. Environ., 26A (11), 2045-2054, 1992.

Zwally, H.J., Growth of Greenland Ice Sheet: Interpretation, Science, 246, 1589-1591, 1989.

E. Isaksson, Norwegian Polar Institute, Middelthunsgate 29, P.B. 5072, Majorstua, N-0301 Oslo, Norway. (e-mail: elli@npolar.no)

W. Karlén, Department of Physical Geography, Stockholm University, S-106 91 Stockholm, Sweden.

N. Gundestrup, The Niels Bohr Institute, Department of Geophysics, University of Copenhagen, Haraldsgade 6, DK-2200 Denmark. (e-mail: ng@gfy.ku.dk).

P. Mayewski, M. Twickler. and S. Whitlow, Glacier Research Group, Institute for the Study of Earth, Oceans and Space, University of New Hampshire, Durham, NH 03824, USA. (e-mail: p-mayewski@unh.edu; mst@unh.edu; siw@unh.edu).

(Received January 15, 1994; revised February 23, 1995; accepted August 3, 1995.) 